\title{
THE OPENING SNAP IN MITRAL INCOMPETENCE
}

\author{
BY \\ P. G. F. NIXON, G. H. WOOLER, AND L. R. RADIGAN \\ From the General Infirmary, Leeds, and the Veterans Administration Hospital, Indianapolis, U.S.A.
}

Received September 24, 1959

The mitral valve opens with a loud snap in some patients suffering from chronic rheumatic heart disease. The features by which the sound may be recognized have been described clearly by Margolies and Wolferth (1932) and by Mounsey (1953). The significance of the opening snap has been disputed. Sellors, Bedford, and Somerville (1953) held it to be reliable evidence of mitral stenosis with a pliant diaphragmatic valve, offering important evidence of operability. Mounsey (1953) did not hear the opening snap in cases where the valves had lost suppleness. Wood (1954) concluded that the opening snap was an important sign of dominant mitral stenosis and an excellent talisman against the presence of serious mitral regurgitation. McDonald et al. (1957) regarded the sound as an important clue to the ease with which mitral stenosis may be surgically relieved. On the other hand, Wood (1954) and McDonald et al. (1957) admitted that an opening snap may occur in addition to the third heart sound of mitral regurgitation: while Goodwin et al. (1955) heard opening snaps in nine out of ten cases of mitral stenosis with important regurgitation. Turner and Fraser (1956) found loud opening snaps in patients with rigid valves, and in patients with dominant mitral regurgitation. Belcher (1956) and Douglas (1957) recognized the fact that mitral opening snaps occurred in cases of incompetence.

The association of a loud opening snap with a pansystolic murmur attributed to mitral regurgitation occurred in thirty patients in a personal series of 250 cases of mitral valve disease. In twelve the valve was examined at operation: without exception the aortic cusp was found to be pliant and mobile, and regurgitation was caused by shrinkage of the mural cusp.

The purpose of this communication is to describe the important features of the twelve cases, and to consider the significance of the opening snap in mitral incompetence.

\section{Clinical Findings}

Eleven of the twelve patients were women and the ages of the group ranged from thirty-six to fifty years. Seven had suffered from rheumatic polyarthritis or chorea in childhood. Disability from breathlessness was moderate or severe in every case. Aortic valve disease was present in three patients, and tricuspid regurgitation in two.

Mitral valve opening and closing snaps and the pansystolic murmur of mitral regurgitation occurred in every case. The opening snaps were readily heard with the stethoscope in patients with dominant stenosis but were sometimes distinguished with difficulty from pulmonary valve closure and the third heart sound in those with dominant regurgitation. Phonocardiography made diagnosis certain by recording aortic and pulmonary valve closure, opening snap, and third heart sound for identification. The intensity of the closing snaps was quite variable, being greater after short rather than long diastolic pauses. The loudness and pitch of the pansystolic murmur of mitral regurgitation appeared to be of little value in the clinical assessment of orifice size.

Consideration of four physical signs permitted the patients with smaller orifices and dominant stenosis to be distinguished before operation from those with larger orifices and dominant regurgitation: the third heart sound of rapid early diastolic left ventricular filling, the presence or absence 
of a tapping cardiac impulse, the presence or absence of a palpable left ventricular thrust, and the quality of the mitral diastolic murmur.

A left ventricular third heart sound occurred in each of the five patients with dominant regurgitation, but in none of the seven with dominant stenosis. In other words, its presence appeared to be conditional upon the mitral orifice measuring $2.5 \mathrm{~cm}$. or more in diameter (Table II).

A left ventricular thrust was palpable at the apex in every patient with dominant incompetence, and in only one with a small orifice: in this instance it was attributed to left ventricular hypertrophy consequent upon aortic valvular disease. The cardiac impulse was tapping in five of the seven patients with dominant stenosis.

The onset of the mitral diastolic murmur tended to be loud, sometimes explosive, in patients with dominant incompetence, while in those with dominant stenosis it began quietly. One patient with dominant stenosis was considered to have a short mitral diastolic murmur, while two patients with large orifices had murmurs lasting throughout diastole. A left atrial systolic murmur was not present in the one patient with dominant incompetence and sinus rhythm.

The important physical findings in the twelve patients with mural cusp disease are shown in Table I. In Table II the surgeon's assessment of mitral orifice size and his description of the cusps are presented. The decision as to whether a patient suffered predominantly from obstruction or regurgitation at the mitral valve was made after the clinical, cardiographic, and radiological features had been considered with the findings from left heart catheterization and from operation.

Phonocardiograms from Cases 10 and 12, suffering from dominant mitral regurgitation are shown in Fig. 4 and 6 . Left atrial pressure pulse records from patients with dominant stenosis

TABLE I

The Important Physical Signs in Twelve Patients with Mural Cusp Disease

\begin{tabular}{|c|c|c|c|c|c|c|c|c|}
\hline Case & Age & $\operatorname{Sex}$ & Rhythm & $\begin{array}{l}\text { Mitral } \\
\text { opening } \\
\text { snap }\end{array}$ & $\begin{array}{l}\text { Mitral } \\
\text { pansystolic } \\
\text { murmur }\end{array}$ & $\begin{array}{l}\text { Cardiac } \\
\text { impulse }\end{array}$ & $\begin{array}{l}\text { Third } \\
\text { heart } \\
\text { sound }\end{array}$ & $\begin{array}{l}\text { Mitral } \\
\text { diastolic } \\
\text { murmur }\end{array}$ \\
\hline \multicolumn{9}{|c|}{ Stenosis Dominant } \\
\hline 1. & 40 & $\mathrm{~F}$ & $\mathrm{AF}$ & Loud & Grade 2 & $\begin{array}{l}\text { L.V. thrust } \\
\text { (aortic stenosis) }\end{array}$ & None & Long \\
\hline 2. & 37 & $\mathbf{F}$ & $\mathrm{AF}$ & Loud & Grade 1 & Tapping & None & Long \\
\hline 3. & 45 & $\mathrm{~F}$ & SR & Loud & Grade 2 & Tapping & None & Long \\
\hline 4. & 44 & $\mathbf{F}$ & $\mathrm{SR}$ & Loud & Grade 3 & - & None & Short \\
\hline 5. & 37 & $\mathrm{~F}$ & SR & Loud & Grade 3 & Tapping & None & Long \\
\hline 6. & 44 & $\mathrm{~F}$ & SR & Loud & Grade 2 & Tapping & None & Long \\
\hline 7. & 45 & $\mathbf{M}$ & SR & Loud & Grade 2 & Tapping & None & Long \\
\hline \multicolumn{9}{|c|}{ INCOMPETENCE DOMINANT } \\
\hline 8. & 50 & $\mathrm{~F}$ & SR & Loud & Grade 3 & L.V. thrust & Present & Long \\
\hline 9. & 36 & $\mathrm{~F}$ & $\mathrm{AF}$ & Loud & Grade 3 & L.V. thrust & Present & Short \\
\hline 10. & 42 & $\mathrm{~F}$ & $\mathrm{AF}$ & Loud & Grade 3 & L.V. thrust & Present & Short \\
\hline 11. & 45 & $\mathrm{~F}$ & $\mathrm{AF}$ & Loud & Grade 2 & L.V. thrust & Present & Long \\
\hline 12. & 37 & $\mathrm{~F}$ & $\mathrm{AF}$ & Loud & Grade 3 & L.V. thrust & Present & Short \\
\hline
\end{tabular}

$\mathrm{SR}=$ Sinus rhythm; $\mathrm{AF}=$ Auricular fibrillation. Murmurs graded 1 to 6 in loudness. 
TABLE II

Findings AT OPERATION

\begin{tabular}{|c|c|c|c|}
\hline Case & $\begin{array}{l}\text { Approximate } \\
\text { diameter of } \\
\text { mitral orifice } \\
\text { (cm.) }\end{array}$ & $\begin{array}{l}\text { Condition of aortic cusp of } \\
\text { mitral valve }\end{array}$ & $\begin{array}{l}\text { Condition of mural cusp of } \\
\text { mitral valve }\end{array}$ \\
\hline \multicolumn{4}{|c|}{ Stenosis Dominant } \\
\hline 1. & $1 \cdot 2$ & Almost normal. Freely mobile & Grossly diseased; thickened and immobile \\
\hline 2. & $1 \cdot 5$ & Mobile, billowing to and fro in the stream & $\begin{array}{l}\text { A thickened ridge of immobile tissue with } \\
\text { calcified vegetations }\end{array}$ \\
\hline 3. & 1.5 & Mobile and pliant & Immobile \\
\hline 4. & $1 \cdot 5$ & Mobile and pliant & Rigid and thickened \\
\hline 5. & $1 \cdot 5$ & Freely movable; ballooning normally & Thickened, narrowed and immobile \\
\hline 6. & 2 & $\begin{array}{l}\text { Reasonably healthy and moving a great } \\
\text { deal }\end{array}$ & Immobile and thickened \\
\hline 7. & 2 & Pliant and mobile & Shrivelled and functionless \\
\hline \multicolumn{4}{|c|}{ INCOMPETENCE DOMINANT } \\
\hline 8. & $2 \cdot 5$ & Pliant and mobile & Functionless \\
\hline 9. & $2 \cdot 5$ & Hardly diseased and very mobile & Immobile, thickened, and rolled upon itself \\
\hline 10. & $2 \cdot 5$ & Pliant and mobile & $\begin{array}{l}\text { Thickened, rolled upon itself, held immo- } \\
\text { bile by short chordæ }\end{array}$ \\
\hline 11. & 3 & Freely mobile and apparently normal & Greatly thickened and rolled upon itself \\
\hline 12. & 3 & Mobile and apparently normal & Thickened, rolled upon itself, and immobile \\
\hline
\end{tabular}

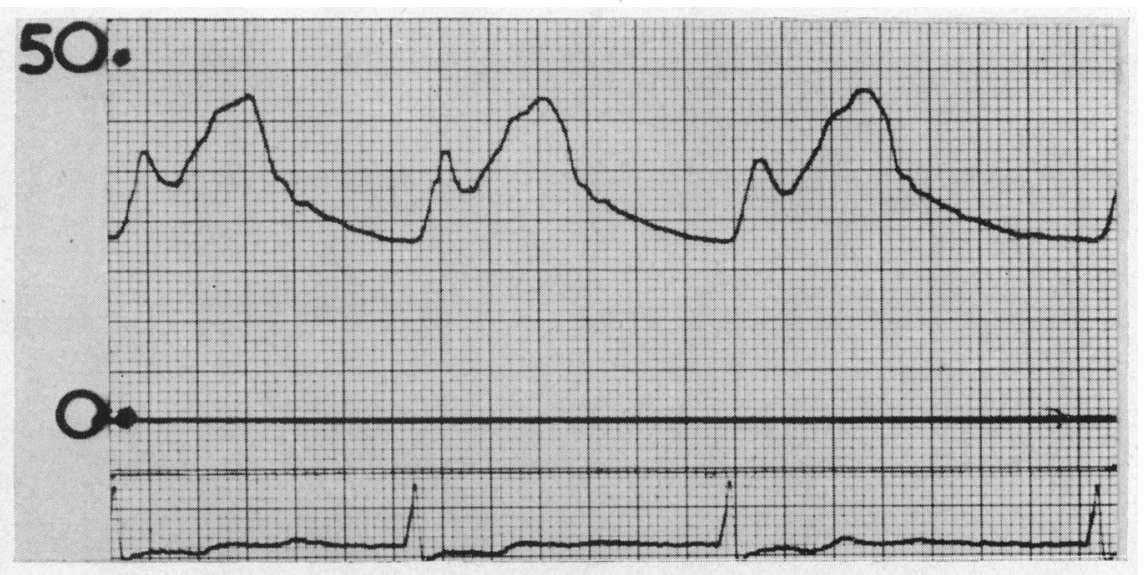

FIG. 1.-Left atrial pressure from Case 1. Mural cusp regurgitation. The dominant mitral lesion was obstructive. (Scale in mm. mercury.) 
L.S. AGED 44 FEMALE
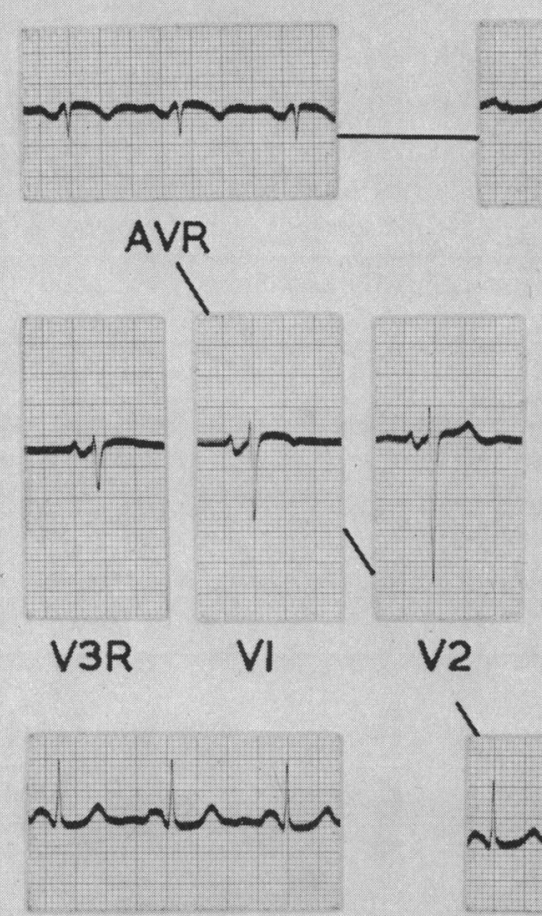

II
1
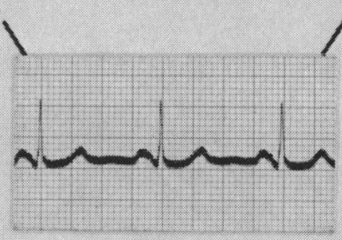

AVF

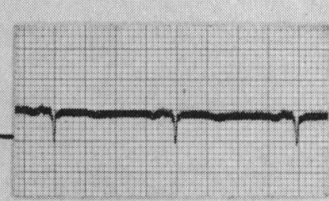

AVL
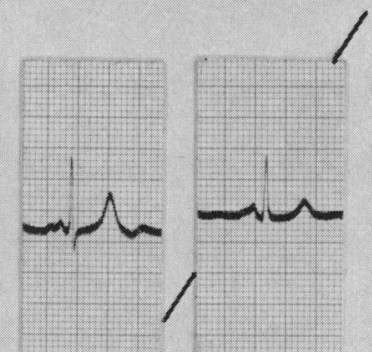

V4

V5

V6

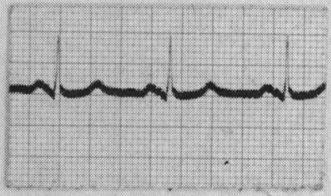

III

Fig. 2.-Electrocardiogram of Case 4. Mural cusp regurgitation. The dominant mitral lesion was obstructive.

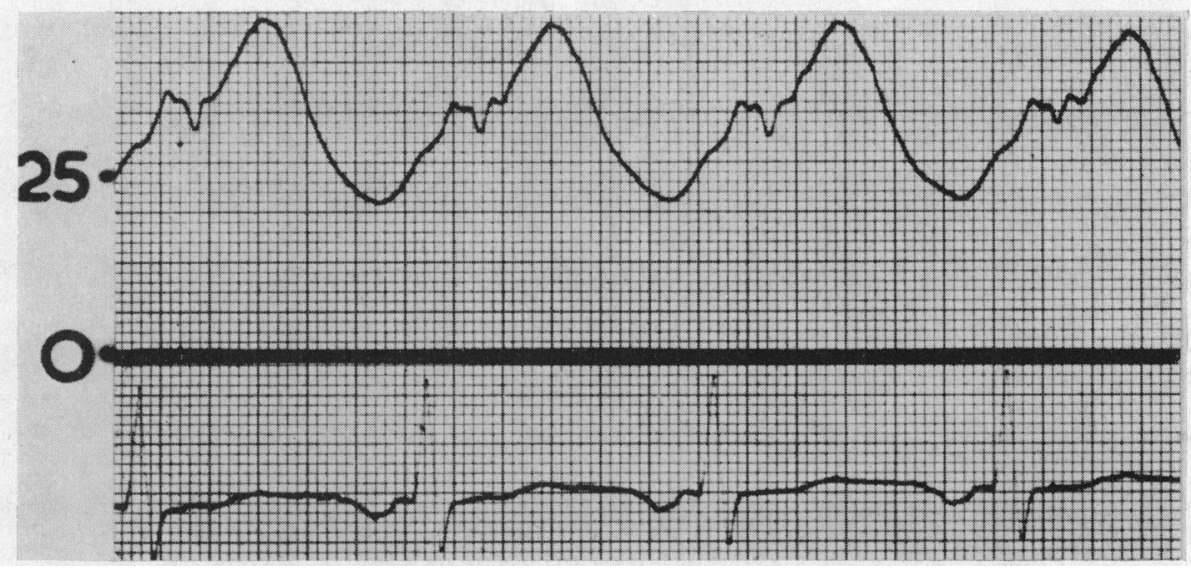

Fig. 3.-Left atrial pressure from Case 8. Mural cusp regurgitation. The dominant mitral lesion was one of regurgitation. (Scale in $\mathrm{mm}$. mercury.) 
and dominant incompetence are shown in Fig. 1 and 3 respectively. The electrocardiogram in Fig. 2 is from a patient with dominant stenosis; that in Fig. 5 from a patient with dominant incompetence. The drawings in Fig. 7 show the artist's impression of the appearance at necropsy of the mitral valve in a case of mural cusp disease.

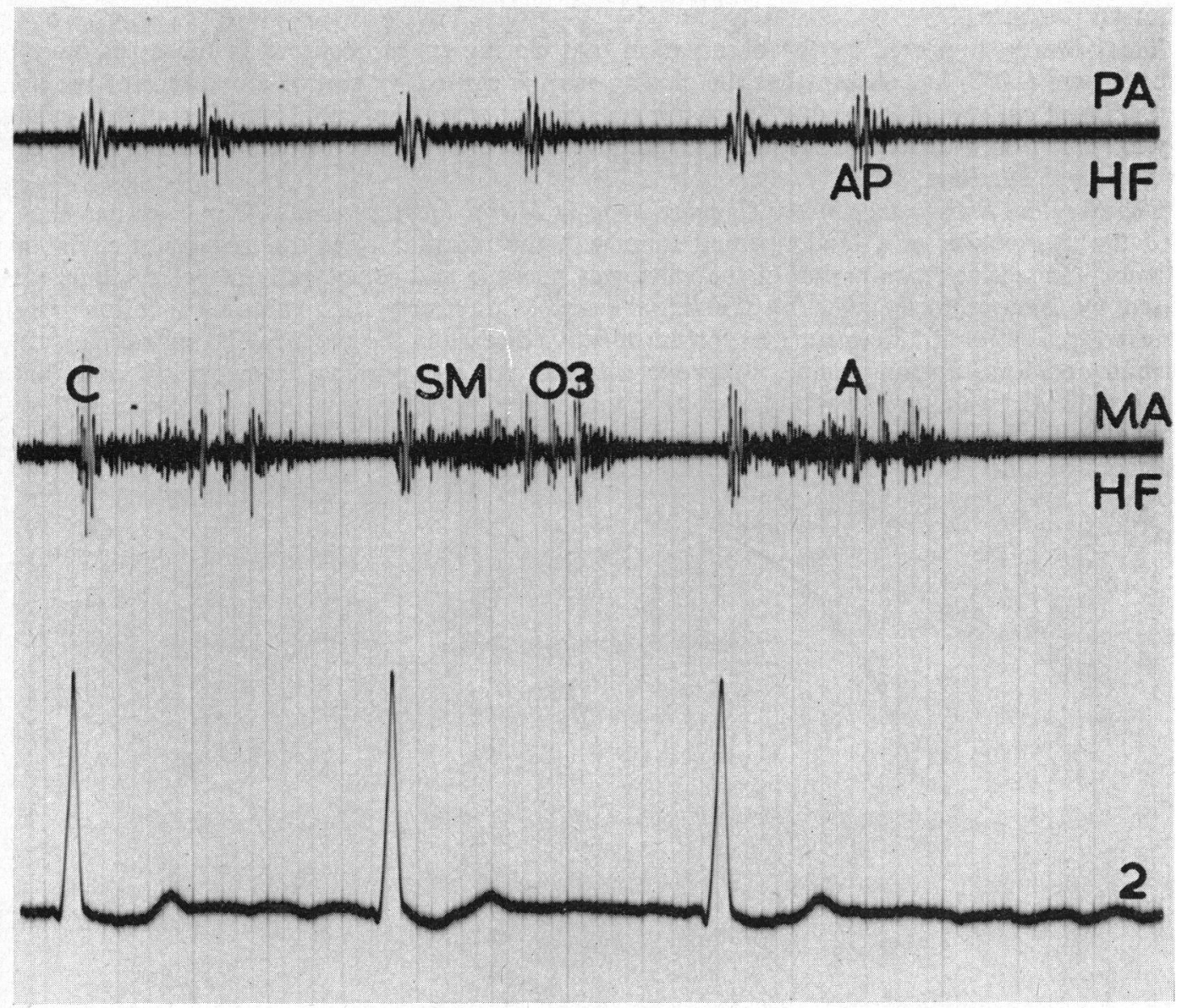

FIG. 4.-High-frequency phonocardiogram from Case 10-dominant mitral regurgitation. P.A.=Pulmonary Area. M.A. = Mitral Area. $A=$ Aortic valve closure. $\mathbf{P}=$ Pulmonary valve closure. $\mathbf{C}=$ closing snap of mitral valve. S.M.=pansystolic mitral murmur. $O=$ Opening snap. $3=$ third heart sound of rapid ventricular filling. $2=$ Lead II electrocardiogram. H.F.=High Frequency.

\section{Discussion}

The Formation of the Opening Snap. In the twelve cases described the important and constant clinical feature was the association of a loud opening snap with the murmur of mitral regurgitation. The important and constant finding at operation was the association of a relatively healthy aortic cusp with regurgitation caused by deformity and immobility of the mural cusp.

Regurgitation ranged from a small stream through a narrow orifice, with a systolic murmur as its only clinical manifestation, to gross reflux through an orifice large enough to permit rapid ventricular filling. It would appear that adhesion between the cusps determined orifice size and consequently the degree of regurgitation. The strength of adhesion between the cusps varied 
from case to case. Surgical separation was easy in some, in others almost impossible. The left atrial pressure was abnormally high in all.

It follows that the opening snap cannot be dependent upon the mitral lesion being purely stenotic, upon commissures that split easily, or upon mobility in the mural cusp. It would appear that the opening snap is caused by a pliant aortic cusp moving abruptly under the influence of a high left atrial pressure.

This view is supported by the observation that closing snaps occurred in the cases described here; Sellors (1952) has shown that the closing snap is caused by abrupt movement of the aortic cusp. Loud closing and opening snaps are uncommon when the mitral valve is grossly calcified (Wynn, 1953), and absent in mitral regurgitation caused by severe disease affecting both cusps (Brigden and Leatham, 1953).

The Surgical Significance of the Opening Snap in Mitral Incompetence. Our team has encountered the association of a loud opening snap with the murmur of mitral regurgitation in thirty patients. In twelve examination of the valve was possible and consistently revealed regurgitation caused by disease chiefly affecting the mural cusp. Conversely, this anatomical lesion has not occurred in a series of 130 operations for mitral valve disease in the absence of a mitral pansystolic murmur and loud opening snap. Moreover, it has appeared possible from clinical examination of the patients to determine whether obstruction or regurgitation was the chief defect. If wider experience confirms the reliability of these physical signs it should be possible to plan the surgical treatment of a disabled patient from clinical examination alone.

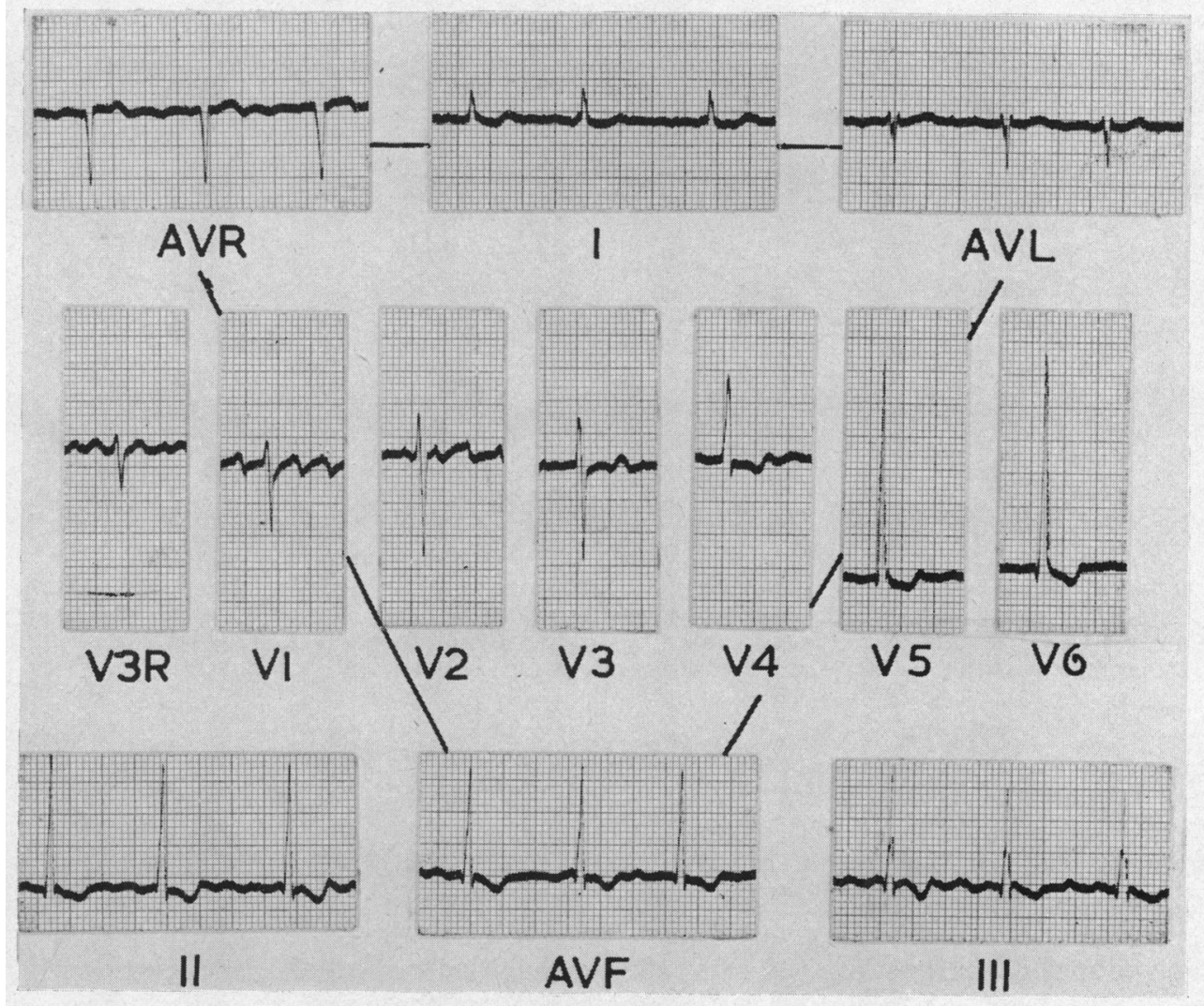

FIG. 5.-Electrocardiogram from Case 10. Dominant mitral regurgitation. 


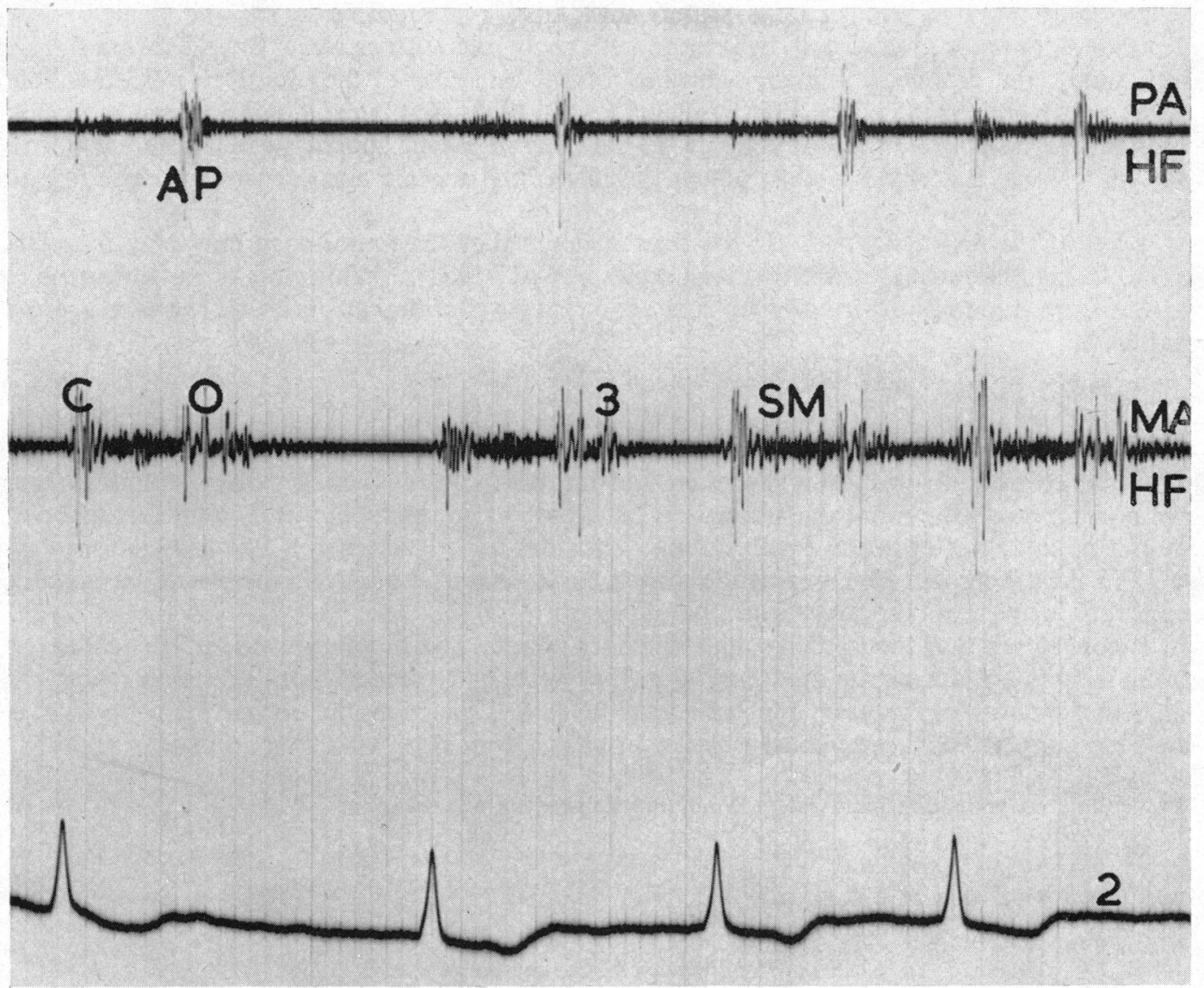

Fig. 6.-Phonocardiogram from Case 12. Dominant mitral regurgitation. Abbreviations as in Fig. 4.

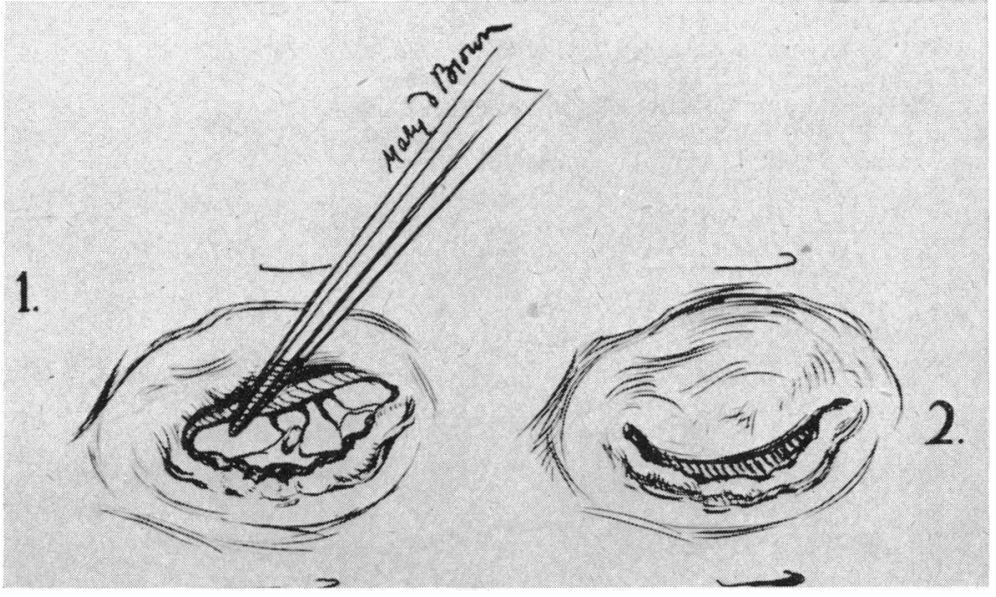

FIG. 7 (1).-A pliant aortic cusp is being retracted to show the shrunken and thickened mural cusp, held by shortened chordæ. (2) The appearance when the atrium is opened, showing that the diseased mural cusp is out of reach of the relatively healthy aortic cusp. 
Valvotomy may relieve patients with mural cusp regurgitation when the orifice is small and stenosis dominant, but cannot help those with negligible obstruction. Provided that the aortic cusp is pliant and mobile, dominant regurgitation from disease of the mural cusp is amenable to surgical treatment (Sakakariba, 1955; Lillehei et al., 1958; Kay et al., 1958; Nixon et al.,1959). At present the operation of choice may be the suturing of plastic sponge to the mural cusp in such a way as to form a cushion against which the pliant and mobile aortic cusp can close in systole (Fig. 7).

Closure of the Mitral Orifice. It has been claimed that the mural cusp may play no effective part in closing the normal mitral orifice (Harken et al., 1951). While this is possibly true, it is apparent from the cases described here that serious regurgitation can result from shrinkage of the mural cusp.

\section{SUMMARY}

Twelve patients are described in whom mitral regurgitation was caused by inability of a pliant and mobile aortic cusp to meet a shrunken and immobile mural cusp, a variety of mitral regurgitation now amenable to surgical treatment. Each patient presented clinically with a loud opening snap and the murmur of mitral regurgitation. If wider experience proves this association of signs reliable in the diagnosis of incompetence caused by disease of the mural cusp it will be of value in the selection of patients for operation.

It is considered that the opening snap indicates pliancy and mobility in the aortic leaflet. The opening snap is not diagnostic of either "pure" stenosis or of commissures that split readily.

Whether or not the mural cusp plays an effective part in closing the normal mitral orifice, considerable regurgitation may be caused by its shrinkage from rheumatic heart disease.

The authors are grateful to Dr. William Whitaker for his advice and criticism.

\section{REFERENCES}

Belcher, J. R. (1956). Lancet, $2,7$.

Brigden, W., and Leatham, A. (1953). Brit. Heart J., 15, 55.

Douglas, D. M. (1957). Brit. med. J., 1, 191.

Goodwin, J. F., Hunter, J. D., Cleland, W. P., Davies, L. G., and Steiner, R. E. (1955). Brit. med. J., $2,573$.

Harken, D. E., Dexter, L., Ellis, L. B., Farrand, R. E., and Dickson, J. F. (1951). Ann. Surg., $134,722$.

Kay, E. B., Nogueira, C., Head, L. R., Coenan, J. P., and Zimmerman, H. A. (1958). J. thoracic Surg., $36,677$.

Lillehei, C. W., Gott, V. L., DeWall, R. A., and Varco, R. L. (1958). J. thoracic Surg., $35,154$.

McDonald, L., Dealy, J. B., Rabinowitz, M., and Dexter, L. (1957). Medicine, 36, 237.

Margolies, A., and Wolferth, C. C. (1932). Amer. Heart J., 7, 433.

Mounsey, P. (1953). Brit. Heart J., 15, 135.

Nixon, P. G. F., Wooler, G. H., and Radigan, L. R. (1959). Circulation, 19, 839.

Sakakariba, S. (1955). Ann. Surg., 142, 196.

Sellors, T. H. (1952). Personal communication to Mounsey, P. (1953).

Sellors, T. H., Bedford, D. E., and Somerville, W. (1953). Brit. med. J., 2, 1059.

Turner, R. W. D., and Fraser, H. R. L. (1956). Lancet, 2, 525.

Wood, P. (1954). Brit. med. J., 1, 1051.

Wynn, A. (1953). Brit. Heart J., 15, 214. 